\title{
Surface structures involved in plant stomata and leaf colonization by Shiga-toxigenic Escherichia coli 0157:H7
}

\author{
Zeus Saldaña ${ }^{1}$, Ethel Sánchez ${ }^{2}$, Juan Xicohtencatl-Cortes ${ }^{3}$ Jose Luis Puente ${ }^{4}$ and Jorge A. Girón ${ }^{1 *}$ \\ Department of Molecular Genetics and Microbiology, Emerging Pathogens Institute, University of Florida, Gainesville, FL, USA \\ 2 Centro de Investigación en Estructuras Microscópicas, Universidad de Costa Rica, San José, Costa Rica \\ ${ }^{3}$ Laboratorio de Bacteriología Intestinal, Hospital Infantil de México Federico Gómez, México D.F., México \\ ${ }^{4}$ Departamento de Microbiología Molecular, Instituto de Biotecnología, Universidad Nacional Autónoma de México, Cuernavaca, Morelos, México
}

\section{Edited by:}

Adel M. Talaat, University of Wisconsin Madison, USA

\section{Reviewed by:}

Michael Konkel, Washington State

University, USA

Jay C. D. Hinton, Trinity College Dublin,

Ireland

\section{${ }^{*}$ Correspondence:}

Jorge A. Girón, Department of

Molecular Genetics and Microbiology,

Emerging Pathogens Institute,

University of Florida, 2055 Mowry

Road, PO Box 100009, Gainesville, FL, 32610, USA.

e-mail: jagiron@ufl.edu
Shiga-toxigenic Escherichia coli (STEC) 0157:H7 uses a myriad of surface adhesive appendages including pili, flagella, and the type 3 secretion system (T3SS) to adhere to and inflict damage to the human gut mucosa. Consumption of contaminated ground beef, milk, juices, water, or leafy greens has been associated with outbreaks of diarrheal disease in humans due to STEC. The aim of this study was to investigate which of the known STEC 0157:H7 adherence factors mediate colonization of baby spinach leaves and where the bacteria reside within tainted leaves. We found that STEC 0157:H7 colonizes baby spinach leaves through the coordinated production of curli, the E. coli common pilus, hemorrhagic coli type 4 pilus, flagella, andT3SS. Electron microscopy analysis of tainted leaves revealed STEC bacteria in the internal cavity of the stomata, in intercellular spaces, and within vascular tissue (xylem and phloem), where the bacteria were protected from the bactericidal effect of gentamicin, sodium hypochlorite or ozonated water treatments. We confirmed that the T3S escN mutant showed a reduced number of bacteria within the stomata suggesting that T3S is required for the successful colonization of leaves. In agreement, non-pathogenic E. coli K-12 strain DH5 $\alpha$ transformed with a plasmid carrying the locus of enterocyte effacement (LEE) pathogenicity island, harboring the T3SS and effector genes, internalized into stomata more efficiently than without the LEE. This study highlights a role for pili, flagella, and T3SS in the interaction of STEC with spinach leaves. Colonization of plant stomata and internal tissues may constitute a strategy by which STEC survives in a nutrient-rich microenvironment protected from external foes and may be a potential source for human infection.

Keywords: plant colonization, stomata, STEC, 0157:H7, pathogenesis, spinach, T3SS, pili

\section{INTRODUCTION}

Human infections due to Shiga-toxigenic Escherichia coli (STEC) O157:H7 strains range from mild diarrhea to bloody diarrhea or hemorrhagic colitis, which can develop into the potentially fatal hemolytic uremic syndrome or HUS (Karmali et al., 1983; Riley et al., 1983). STEC is a significant dilemma in the realm of food-borne disease, exemplified in recent episodes of diarrheal disease in various regions of the world associated with consumption of contaminated food, water, milk, fruit juices, and leafy green vegetables such as alfalfa, sprouts, arugula, spinach, and lettuce (Michino et al., 1999; Sivapalasingam et al., 2004; Wendel et al., 2009). The precise mechanisms by which STEC is introduced into agricultural products are not fully understood. The bacteria live as commensal organisms in farm and several wild animals and may represent a major source of contamination of water and agricultural produce for human consumption (Solomon et al., 2002; Mootian et al., 2009). For example, recent outbreaks of diarrheal illness associated to spinach consumption were linked to contamination with feces from STEC-harboring wild pigs (CDC, 2006; Jay et al., 2007). Insects (e.g., filth flies) have been implicated as transmission vectors in plant infection by STEC (Talley et al., 2009).
The phyllosphere supplies an important bio-niche for a significant number and wide range of commensal bacterial species as well as for plant and human pathogens (Lindow and Brandl, 2003). Pathogen-associated molecular patterns (PAMPs) such as flagella and lipopolysaccharide (LPS) from Gram-negative bacteria interact with specific target receptors on guard cells to elicit an innate response resulting in the closure of stomata on the Arabidopsis leaf surface (Melotto et al., 2006). Illness-producing bacteria have evolved strategies to overcome plant defenses and to colonize the surface of leaves and deeper tissues of the phyllosphere. They use wounds and natural openings like stomata, hydathodes, and lenticels as natural gateways for passage into internal plant tissues where they grow and begin to cause disease (Hirano and Upper, 2000; Melotto et al., 2006). Pseudomonas syringae, a pathogen of hundreds of plant species utilizes its secretion (type 3 secretion system, T3SS) and an array of effector molecules to successfully suppress plant innate mechanisms of defense and kill its host (Chang et al., 2005; Chisholm et al., 2006). Listeria monocytogenes uses flagella for attachment to radish tissue and Klebsiella, Enterobacter, and Pseudomonas produce fimbriae that mediate attachment to plant surfaces (Korhonen et al., 1986; Vesper, 1987; Gorski et al., 2003). It was suggested that E. coli $\mathrm{O} 157: \mathrm{H} 7$ is able to exist as a component 
of the phyllosphere microbial community both as epiphytes on leaf surfaces and endophytes within leaf tissues. While some authors suggest that E. coli O157:H7 could be absorbed from soil to internal plant tissues, others suggest entry through plant roots (Wachtel et al., 2002; Islam et al., 2004; Jablasone et al., 2005; Sharma et al., 2009). E. coli O157:H7 can be located and is able to survive in the substomatal cavity and the intercellular spaces of the spongy of leafy greens (Itoh et al., 1998; Solomon et al., 2002; Warriner et al., 2003; Franz et al., 2007). The precise mechanisms of adherence of STEC to plant surfaces, the receptors recognized, and the types of physical interactions participating in this interplay are largely unknown.

Much is known about the mechanisms of interaction of STEC with human epithelial cells. STEC uses its T3SS to inject many effector proteins into intestinal cells that lead to remodeling of the cytoskeleton and consequently to the formation of intestinal attaching and effacing (AE) histopathological lesions. Most of the components required for $\mathrm{AE}$ are encoded in the genetic locus of enterocyte effacement (McDaniel and Kaper, 1997). It is well established that the interaction of STEC with human epithelial cells is multi-factorial as it involves the participation of the intimin-Tir complex, secreted proteins, and flagella. Several pili types including, but not limited to, the long polar fimbriae, F9, hemorrhagic coli pilus (HCP), curli, the E. coli laminin-binding fimbriae (ELF), and the $E$. coli common pilus (ECP), were associated with adherence to human and animal epithelial cells in vitro (Torres et al., 2002; Kaper et al., 2004; Low et al., 2006; Erdem et al., 2007; Rendon et al., 2007; Xicohtencatl-Cortes et al., 2007; Saldana et al., 2009; Samadder et al., 2009). It was reported that the EspA fiber, but not intimin, flagella or pili, was required for attachment of STEC to arugula leaves (Shaw et al., 2008). Recently, we suggested that the T3SS of STEC O157:H7 aids in the colonization of lettuce and spinach (Xicohtencatl-Cortes et al., 2009).

The aim of this study was focused on expanding our knowledge on the interaction of STEC with baby spinach leaves and the role of newly described surface adherence factors in colonization. This effort revealed that STEC uses several surface structures to colonize the leaf surface and gain access to internal tissues and in this way, establish a niche in the plant where bacteria are protected from environmental foes and industrial decontamination. This strategy would ensure survival in the environment and allow transmission to animal reservoirs and to the human host.

\section{MATERIALS AND METHODS BACTERIAL STRAINS AND CULTURE CONDITIONS}

Strains used here are described in Table 1 . Bacteria were routinely grown overnight at $37^{\circ} \mathrm{C}$ with aeration in Luria-Bertani (LB) broth or for induction of virulence factors in Dulbecco's modified Eagle's medium (DMEM) with 0.5\% D-mannose (Invitrogen). Except for the intimin (eae), quorum sensing ( $q s e \mathrm{~B})$, and Tir (tir) mutants constructed here, all of the remaining mutants and complemented strains employed have been reported previously by our laboratories or other researchers.

\section{CONSTRUCTION OF BACTERIAL MUTANTS}

The tir, eae, and qseB genes in STEC O157:H7 strain EDL933 were deleted by the $\lambda$ Red recombinase mutagenesis approach as described earlier (Datsenko and Wanner, 2000). The primers
Table 1 | Bacterial strains and plasmids used in this study.

\begin{tabular}{|c|c|c|}
\hline Strains source & Notes & References or source \\
\hline EDL933 & Wild type 0157:H7 & Riley et al. (1983) \\
\hline EDL933 $\Delta e s c N$ & T3SS-ATPase escN::km & Jarvis and Kaper (1996) \\
\hline EDL933ડtir & Tir mutant tir::km & This study \\
\hline EDL933 & Intimin mutant eae::km & This study \\
\hline EDL933 & espFu::cm & Campellone et al. (2004) \\
\hline EDL933 $\Delta$ espP & espP::km & Xicohtencatl-Cortes et al. (2010) \\
\hline EDL933 $\Delta$ fliC & fliC::km & Erdem et al. (2007) \\
\hline EDL933 $\Delta q s e B$ & $q s e B:: \mathrm{cm}$ & This study \\
\hline EDL933 $\Delta h c p A$ & hсpA::km & Xicohtencatl-Cortes et al. (2007) \\
\hline EDL933 $\triangle е c p A$ & ecpA::km & Rendon et al. (2007) \\
\hline EDL933 $\Delta$ elfA & elfA::km & Samadder et al. (2009) \\
\hline EDL933 $\Delta \operatorname{csg} A$ & $\operatorname{csg} A:: \mathrm{km}$ & Saldana et al. (2009) \\
\hline EDL933 $\Delta \operatorname{csg} A$ & $\mathrm{pCsg} A=\operatorname{csg} B A$ & Saldana et al. (2009) \\
\hline (pCsgA) & in pBAD-Topo & \\
\hline $\mathrm{EDL933 \Delta csgD}$ & $\operatorname{csg} D:: \mathrm{km}$ & Saldana et al. (2009) \\
\hline EDL933 $\Delta c s g D$ & pCP994 = csgD in & Saldana et al. (2009) \\
\hline (pCP994) & pKK233-2 & \\
\hline EDL933 $\Delta b c s A$ & $b c s A:: c m$ & Saldana et al. (2009) \\
\hline $\mathrm{DH} 5 \alpha$ & $\mathrm{K}-12$ strain & Our collection \\
\hline $\mathrm{DH} 5 \alpha$ (pLEE) & LEE plasmid & This study \\
\hline
\end{tabular}

employed for mutagenesis are described in Table 2. The isogenic mutants were confirmed for the lost genotype by PCR. All mutant derivatives grew at the same rate as the wild-type strain under the conditions tested in this work.

\section{SPINACH COLONIZATION ASSAYS}

Fresh processed baby spinach leaves (cut into $1 \mathrm{~cm}$-diameter pieces) were washed with sterile PBS and placed into 24-well plates containing DMEM with $0.5 \%$ D-mannose. The leaves were then infected with approximately $10^{7}$ bacteria from an overnight culture grown in $\mathrm{LB}$ broth and incubated at $26^{\circ} \mathrm{C}$ for specific time periods $(0-24 \mathrm{~h})$ or as indicated in the text. The supernatant was then removed and the leaves were washed three times with sterile PBS to remove unbound bacteria. For quantitative assessment of bacterial adherence, spinach leaves infected with wild type or isogenic mutants were placed in $1.5 \mathrm{ml}$ Eppendorf tubes containing glass beads in $1 \mathrm{ml}$ of sterile PBS with $0.3 \%$ Triton X-100 and vortexed for $5 \mathrm{~min}$. The supernatant was collected and 10-fold serial dilutions were plated out onto MacConkey-Sorbitol agar plates for determination of colony-forming units (CFUs) after overnight incubation (Xicohtencatl-Cortes et al., 2009). When required, the infected leaves where incubated for $2 \mathrm{~h}$ with gentamicin $(200 \mu \mathrm{g} / \mathrm{ml})$ to kill surface-exposed bacteria, and the bacteria inside the leaves tissues surviving this treatment, were counted as described above. All experiments were repeated at least three times in triplicate on different days and the results were expressed as percentage of adherence relative to that of the wild-type strain or as CFUs.

\section{ELECTRON MICROSCOPY STUDIES}

For transmission electron microscopy (TEM) infected and mockinfected leaves were washed as described above and fixed with fixative Trumps (Electron Microscopy Sciences). Fixed tissues were 
Table 2 | List of primers used in this study.

\begin{tabular}{|c|c|c|c|}
\hline Primer name & Gene & Function & Primer Sequence $5^{\prime} \rightarrow 3^{\prime}$ \\
\hline \multirow[t]{2}{*}{ K1 $f$} & $\mathrm{~km}$ & Confirm mutagenesis & GTGTATTGACGGCGTTTATAACTGTGGTATGTGCA \\
\hline & & & ACGTCCAGCGTTATGGTGTAGGCTGGAGCTGCTTC \\
\hline K2 r & & & CCGTCATATGAATATCCTCCTTAG \\
\hline $\mathrm{H}$ tir-H1P1 f & tir & Mutagenesis & AATAAAAAGGAGATATTTATGCCTATTGGTAATCTTGGTCATTGTAGGCTGGAGCTGCTTCG \\
\hline $\mathrm{Heae}-\mathrm{H} 2 \mathrm{P} 2 \mathrm{r}$ & eae & Mutagenesis & GCCGGGGTGGTTATGGAATTATTCTACACAAACCGCATAGACCATATGAATATCCTCCTTAG \\
\hline G250 f & qseB & Mutagenesis & TATCGCAGGGATGAAAAAATGCGAATTTTACTGATAGAAGTGTAGGCTGGAGCTGCTTC \\
\hline G251r & $q \operatorname{se} B$ & Mutagenesis & CTCACCTAATGTGTAGCCAATACCATGCTCGGTACGAATCATATGAATATCCTCCTTAG \\
\hline Htirf & tir & Confirm mutagenesis & GGTTGCTGCAATTTTATTTAT \\
\hline Hetir $r$ & tir & Confirm mutagenesis & TGAAATAGATCCAATACCAATT \\
\hline
\end{tabular}

F, forward; r, reverse.

processed with the aid of a PelcoBioWave laboratory microwave (Ted Pella). The samples were washed in $0.1 \mathrm{M}$ sodium cacodylate $\mathrm{pH} 7.2$, post fixed with $2 \% \mathrm{OsO}_{4}$, water, washed, and dehydrated in a graded ethanol series $25,50,75,95,100 \%$ followed by $100 \%$ acetone. Dehydrated samples were infiltrated in graded acetone/ Spurs epoxy resin $(30,50,70,100 \%)$, and cured at $60^{\circ} \mathrm{C}$ for $48 \mathrm{~h}$. Cured resin blocks were trimmed, thin sectioned, and collected on Formvar copper slot grids, post-stained with $2 \%$ aq. Uranyl acetate and Reynolds' lead citrate. Sections were examined with a Hitachi H-7000 TEM (Hitachi High Technologies America) and digital images acquired with a Veleta $2 \mathrm{k} \times 2 \mathrm{k}$ camera and iTEM software (Olympus Soft-Imaging Solutions Corp.). For scanning electron microscopy (SEM), infected and mock-infected leaves were fixed, dehydrated as mentioned above and critically point dried (Bal-Tec CPD030, Leica Microsystems). Samples were mounted on carbon adhesive tabs on aluminum specimen mount, $\mathrm{Au} / \mathrm{Pd}$ sputter coated (DeskV, Denton Vacuum), and examined with highresolution field-emission scanning electron microscope (S-4000, Hitachi High Technologies America).

\section{ANTISERA}

Rabbit polyclonal antibodies raised against STEC antigens, H7 flagella, O157 LPS, ECP, and curli, were available from previous studies and their specificity has been previously described (Rendon et al., 2007; Saldana et al., 2009; Xicohtencatl-Cortes et al., 2009).

\section{LIGHT AND IMMUNOFLUORESCENCE MICROSCOPY}

Infected leaves were washed three times with sterile PBS to remove unbound bacteria and then fixed with $2 \%$ formalin/PBS for $20 \mathrm{~min}$. Peels of the lower surfaces of the leaves (epidermis abaxial) were observed by light microscopy to visualize bacteria associated with or within stomata openings as previously described (Melotto et al., 2006). For immunofluorescence microscopy (IFM), leaves fixed with $2 \%$ formalin, were incubated for $1 \mathrm{~h}$ with primary rabbit antibodies (listed above) followed by 1 -h incubation with secondary anti-rabbit IgG Alexa-conjugated antibodies (Molecular Probes). The specimens were visualized under UV light and phase contrast using an Axio Imager1.0 Zeiss microscope.

\section{RESISTANCE TO OZONATED WATER AND CHLORINATED SOLUTIONS}

To determine resistance to chlorine treatment, leaves of approximately the same size were placed in Petri dishes and were infected at $26^{\circ} \mathrm{C}$ for $9 \mathrm{~h}$ with approximately $10^{7}$ bacteria from overnight cultures grown in DMEM. After the desired incubation period, the spinach leaves were subjected to $10 \mathrm{~min}$-washes in 10-fold dilutions (0.1-10\%) of sodium hypochlorite (chlorine), or 10-20 min exposure to ozonated water. Subsequent to this treatment, the spinach leaves were washed three times with sterile PBS, cut into $1 \mathrm{~cm}$ diameter pieces, and placed in $1.5 \mathrm{ml}$ Eppendorf tubes containing $1 \mathrm{ml}$ of sterile PBS with $0.3 \%$ Triton X-100 and glass beads and processed as described above for bacterial counting (XicohtencatlCortes et al., 2009). Statistical analysis was done using Student's $t$-test. The significance level was $5 \%$ in all tests $\left({ }^{*} P<0.05\right)$. The GraphPad software was used.

\section{RESULTS}

\section{ROLE OF FLAGELLA AND T3SS IN LEAF COLONIZATION}

We sought to investigate the importance of these surface structures in leaf adherence and colonization. Kinetics studies of spinach infections performed between 0 and $8 \mathrm{~h}$ assisted by IFM using specific anti-H7 antibodies revealed the compelling presence of flagella on bacteria adhering to the leaf epidermis. Progressive and increasing amounts of flagella $\mathrm{H} 7$ were observed correlating with the increasing number of bacteria adhering with respect to time of incubation (Figure 1). SEM analysis of wild type versus a genetically modified flagella (non-motile) mutant supported these observations (Figure 1G). Comparative quantitative experiments showed that the flagella $(f l i C)$ and T3SS $(\operatorname{escN})$ mutants adhered significantly less than the parental strain confirming a role of these appendages in spinach colonization (Figure 2A). We 

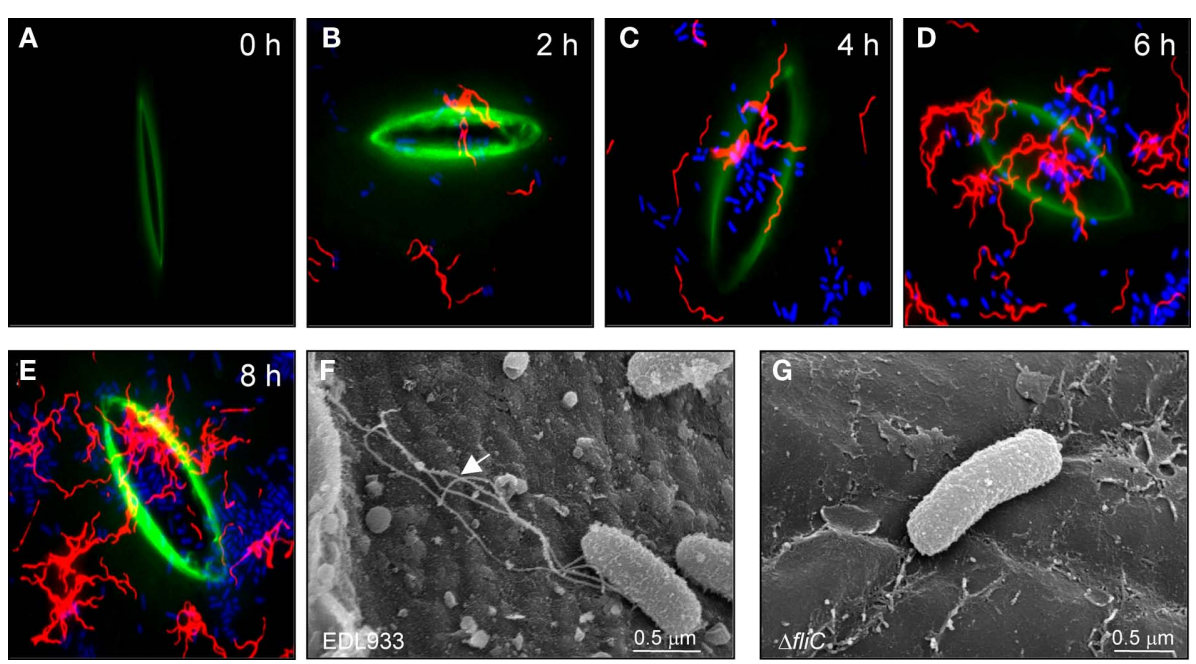

FIGURE 1 |Time-course visualization of flagella on STEC infecting spinach leaves. (A-E), Leaves infected with STEC for 0, 2, 4, 6, and $8 \mathrm{~h}$ were processed for IFM using anti-H7 antibodies. Flagella are shown in red, bacteria in blue, and the stomata in green. Images were taken at 60X. (F) Scanning electron micrograph showing EDL933 adhering onto the leaf epidermis and displaying flagella (arrow). (G) The fliC mutant did not show the structures seen in (F).

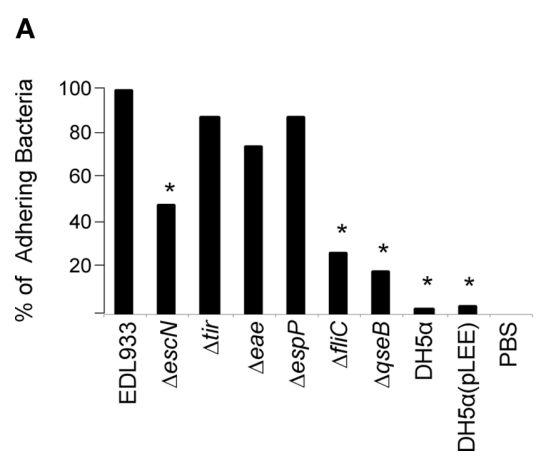

B

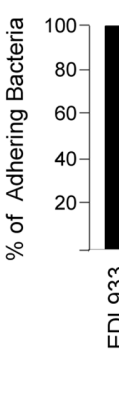

FIGURE 2 | Comparative analysis of spinach colonization by STEC strains after $\mathbf{9} \mathbf{h}$ of infection. (A) EDL933 and isogenic mutants in escN (T3SS), tir (intimin receptor), eae (intimin), espP (toxin/adhesin), fliC (flagellin), and qse $B$ (quorum sensing gene). (B,C) EDL933 and isogenic mutants in pilin genes: hcpA, ecpA, elfA, csgA, csgD (curli regulator), or bcsA (cellulose). All of the strains were used to infect spinach leaves as described in the text. Serial dilutions of homogenized samples were plated out onto MacConkey-Sorbitol plates for bacterial counting. These data represent the average of three experiments repeated on different days in triplicate. ${ }^{*} P>0.05$ statistically significant with respect to the wild-type strain. sought to determine if the intimin-Tir complex was important for spinach colonization. This analysis showed that intimin (eae) and Tir (tir) mutants were not significantly abrogated in adherence suggesting that the intimin-Tir interaction is not crucial or necessary for leaf colonization, as it is for human cells. Since the EspP cytotoxin was suggested to play a role in bovine colonization and forms adhesive macrostructures (Dziva et al., 2007; Xicohtencatl-Cortes et al., 2010), we included this mutant in our analysis. The espP mutant was not significantly affected in leaf colonization (Figure 2A).

\section{ROLE OF QUORUM SENSING IN LEAF COLONIZATION}

Quorum-sensing regulates many virulence-associated functions in bacteria such as flagellation, motility, and T3S (Sperandio et al., 2001). We found that a quorum-sensing mutant $(\Delta q s e B)$ was reduced in adherence by $80 \%$ as compared to the wild-type strain (Figure 2A) and this result correlates with the observation that the flagella $(f l i C)$ and T3SS $(e s c N)$ mutants were significantly hampered (72 and 52\% reduction, respectively) in spinach colonization.

\section{STEC PILI TYPES INVOLVED IN THE COLONIZATION OF BABY SPINACH \\ LEAVES}

The specific adherence molecular mechanisms that mediate phyllosphere colonization by STEC remain elusive. Hence, we investigated the role of recently described surface factors of STEC in adherence to spinach leaves. To this aim, isogenic strains carrying mutations in genes encoding for HCP, ECP, ELF, curli, and cellulose were tested for leaf adherence in comparative quantitative experiments. We found that the $\operatorname{csg} A$ and $\operatorname{csg} D$ (99\% reduction), ecpA (83\% reduction), and $h c p A$ ( $49 \%$ reduction) mutants were significantly hampered in adherence to baby spinach leaves in comparison to 
the parental strain EDL933 (Figures 2B,C). Notably, when the csgA and $\operatorname{csg} \mathrm{D}$ mutants were complemented with plasmids (pCsgA and pCP994 respectively) that over express curli (Saldana et al., 2009), the resulting strains attached more than the wild-type strain to the spinach leaves (Figure 2C). The remaining ELF and cellulose mutants were not deficient in spinach colonization (Figure 2C). The presence of ECP and curli on the bacteria colonizing the leaf epidermis was demonstrated by IFM using specific antibodies against these pili structures (Figure 3). Mutants in curli and ECP served as negative controls for production of these pili. In all, the IFM data compellingly indicate that flagella, ECP, and curli are present during the interaction of the colonizing bacteria with the spinach leaves and participate collectively in adherence and colonization.

\section{LOCALIZATION OF STEC WITHIN LEAF TISSUES}

Previous studies have shown STEC bacteria on leaf surfaces, on and around stomata, and between cellular spaces and xylem (Itoh et al., 1998; Solomon et al., 2002; Warriner et al., 2003; Franz et al., 2007). We sought to further investigate the ability of STEC to reside within the stomata internal cavity and internal tissues. SEM analysis of spinach leaves incubated from 1 to $24 \mathrm{~h}$ with EDL933 revealed the presence of increasing number of bacteria on the stomata and within its internal cavity (Figures $4 \mathrm{~A}-\mathrm{F}$ ). Scores of bacteria tethered by filamentous appendages resembling flagella were noted (Figure 4B). Accompanying IFM experiments using anti-O157 LPS antibody showed compelling localization of STEC O157 bacteria on stomata and internalized within stomata cavities (Figures $4 \mathbf{G}-\mathbf{J}$ ). Further, analysis of cross sections of infected leaves confirmed

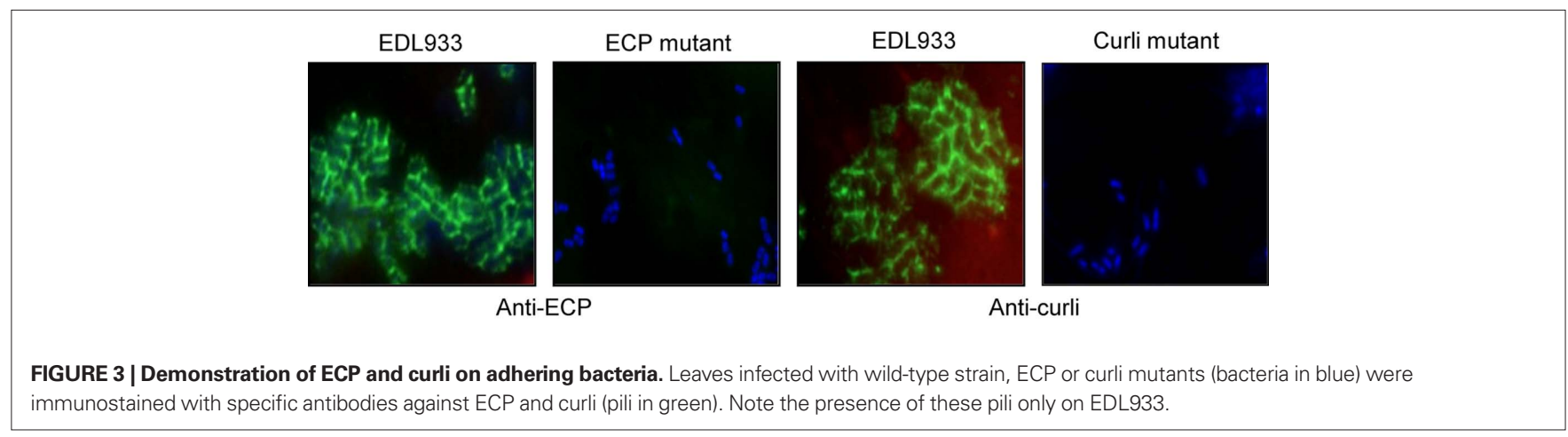

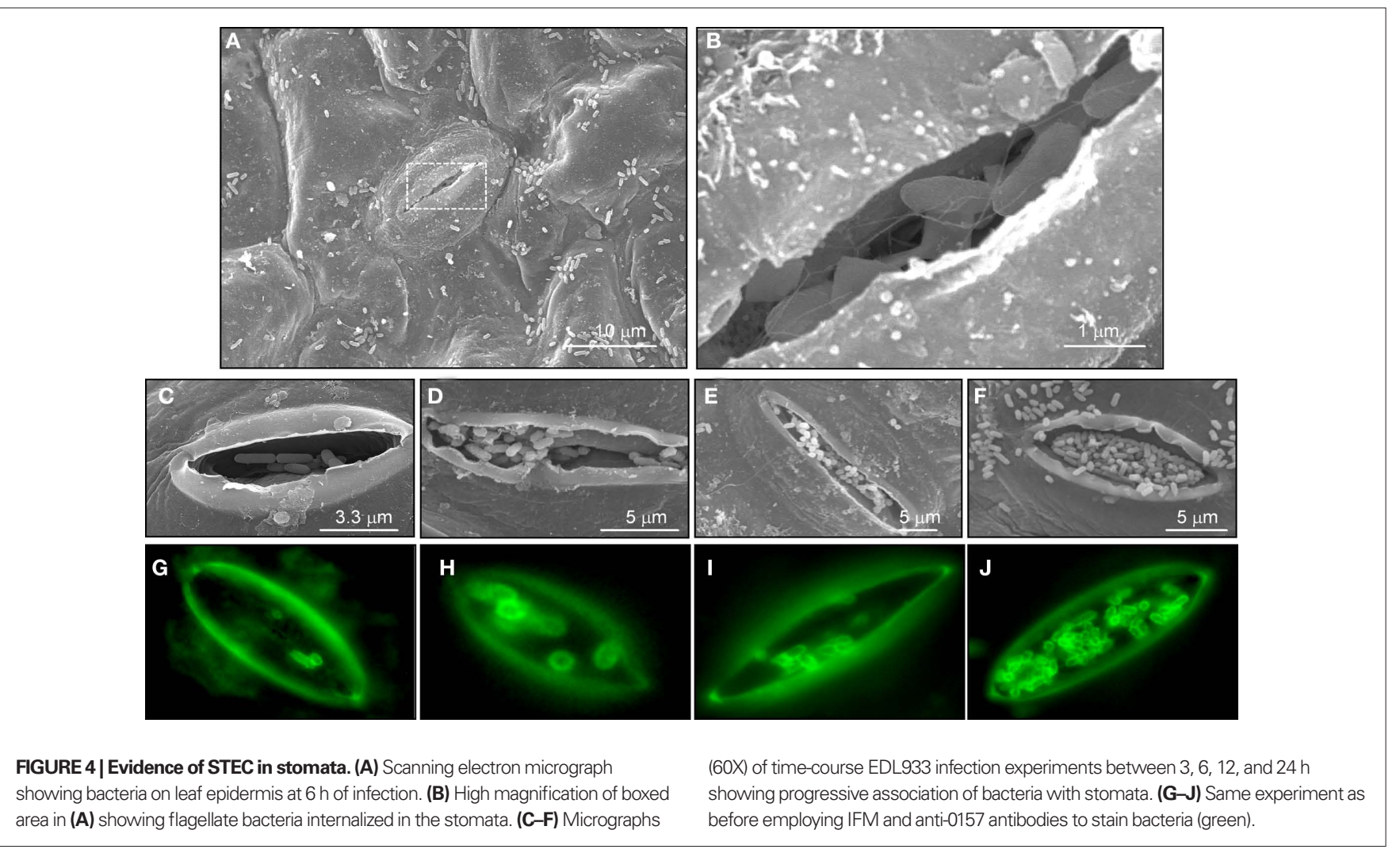


the presence of STEC bacteria within stomata internal cavities, intercellular spaces of the spongy mesophyll, and notably in the vascular tissue (xylem and phloem; Figure 5).

Based on these observations, we hypothesized a role for T3SS in leaf internalization. Thus, we then compared the ability of EDL933 versus the $\operatorname{esc} N$ mutant to penetrate the leaf surface using the gentamicin protection assay. We found that EDL933 survived at a rate of $8.3 \%$ after gentamicin treatment, while the escN mutant showed $6.1 \%$ survival (data not shown). A more clear involvement of T3SS was seen when E. coli $\mathrm{K}-12 \mathrm{DH} 5 \alpha$ and $\mathrm{DH} 5 \alpha$ carrying the LEE region, which encodes the T3SS on a plasmid (pLEE), were included in the assay. Leaves infected with DH5 $\alpha$ (pLEE) showed 3.2-fold-increase with respect to the DH5 $\alpha$ strain (data not shown). Other workers have shown STEC and enteroaggregative E. coli adhering to the leaf epidermis, and on and around stomata but not beyond the substomal chamber (Berger et al., 2009, 2010; Xicohtencatl-Cortes et al., 2009). Based on previous observations and our own, we hypothesized that E. coli O157:H7 are able to provide for themselves with a safe, nutrient-rich niche in the womb of stomata, internal tissues, and intercellular spaces of the leaf, where they are able to replicate and survive, protected from environmental foes.
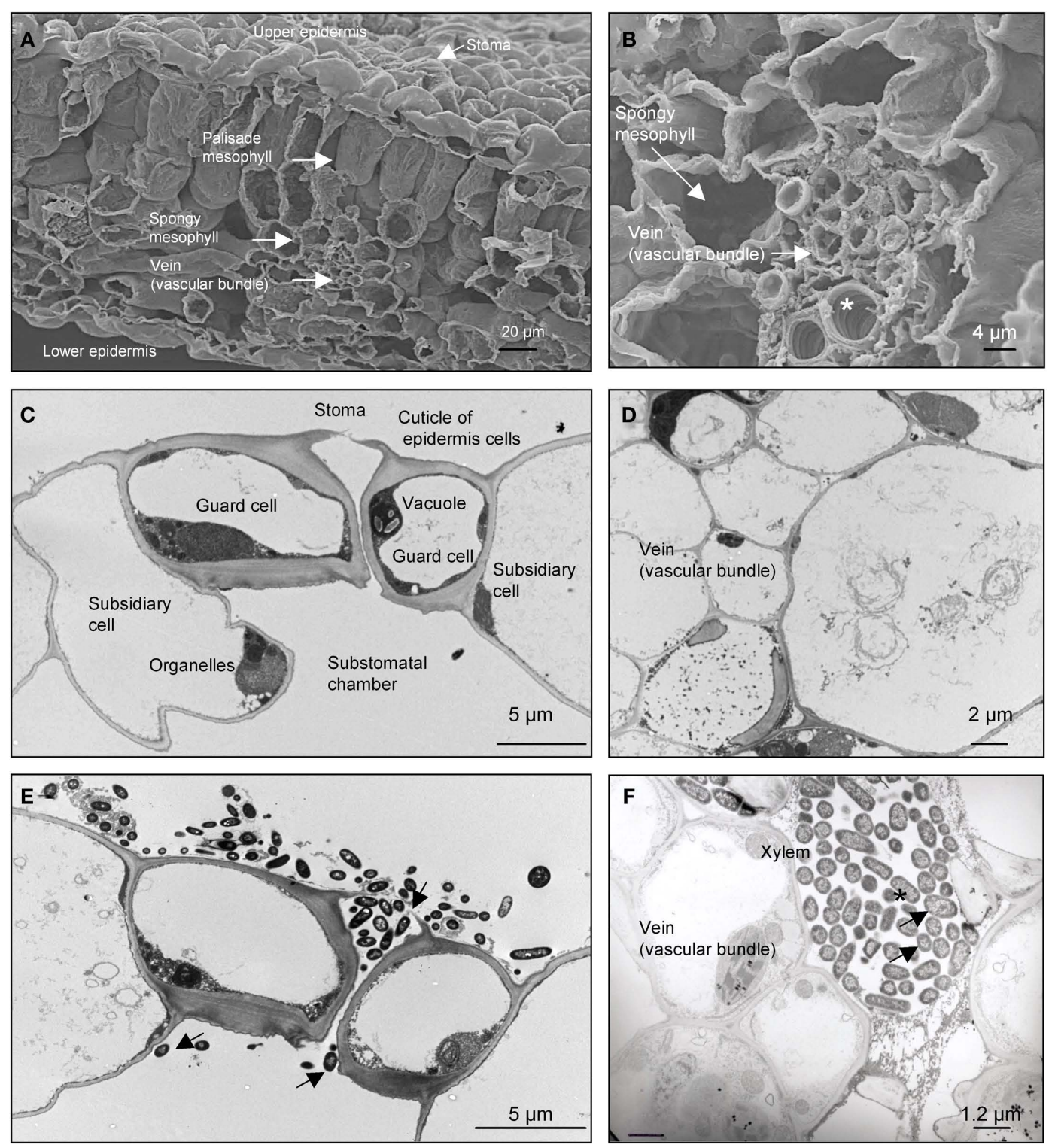

FIGURE 5 | Evidence of STEC present in stomata chambers and in leaf vein. (A) SEM image showing a cross section of uninfected leaf. (B) Close up of the internal tissue of the leaf showing the vascular bundle and spongy mesophyll structures. (C,D) TEM images showing cross sections of uninfected leaf after $24 \mathrm{~h}$ in DMEM. Anatomical sites are indicated with arrows. (E) Cross section of leaf infected with EDL933 (arrows) for $24 \mathrm{~h}$ revealing colonization on the cuticle of the epidermis, stomata, and the substomatal chamber. (F) Cross section showing internal structures of the spinach leaf and colonization of the vessel elements of the xylem with STEC (arrows) 


\section{LEAF INTERNALIZATION PROVIDES PROTECTION AGAINST BACTERICIDAL AGENTS}

Is stomata colonization a "hide-n-sick" mechanism by which STEC evades industrial decontamination of agricultural products for human consumption? In an attempt to address this important question we subjected experimentally STEC-tainted spinach leaves to decontamination treatments with $0.1-10 \%$ of hypochlorite solutions and also to exposure to ozonated water. First, we showed that $10 \%$ sodium hypochlorite (equivalent to 6,500 ppm) and $125 \mathrm{ppm}$ of ozonated water killed 100 and $99.9 \%$ of the bacteria, respectively (Figures 6B,D). Second, we subjected STEC-infected leaves to the same treatments after which bacteria were still recovered (Figures 6A,C). Although these anti-bacterial agents reduced the bacterial population on the leaves by $\sim 50 \%$ as compared to the mock control, it is clear that a striking number of bacteria residing in the stomata resisted and survived these bactericidal treatments. A reasonable explanation for these results is that internalization of bacteria into stomata and internal compartments of the leaf protected bacteria from bactericidal agents such as antibiotics (e.g., gentamicin), chlorine or ozone.

\section{DISCUSSION}

The present study was initiated to address important questions concerning the interaction of STEC with spinach leaves. Specifically, we wanted to identify which of the adhesive factors of STEC, known to be important for human and animal intestinal epithelial cell infection, are also engaged in colonization and survival of these bacteria in baby Spinacia oleracea leaves. Several lines of evidence, obtained through different experimental approaches support the notion of the participation of flagella in baby spinach leaf colonization. We demonstrated in time-course experiments assisted by high-resolution SEM and IFM that the bacteria multiply and colonize the leaf surface and that flagella are produced progressively. In support of these observations, we found that an EDL933 fliC (flagella) isogenic mutant exhibited significant decreased attachment to spinach leaves. In line with our data, Carey et al. (2009) found that fliC was up-regulated during storage of Romaine lettuce at $15^{\circ} \mathrm{C}$. It is apparent the flagella display other functions than motility.

A unifying theme in animal and plant bacterial pathogens is the production of specialized secretion mechanisms for direct delivery of effector proteins into host cells to inflict damage. Plant pathogens such as Pseudomonas and Agrobacterium employ flagella, pili, T3SS or T4SS to infect and cause phytopathology, although the nature of their receptors remains unknown (Korhonen et al., 1986; Rahme et al., 1995; McCullen and Binns, 2006). Flagellation and T3S of STEC are regulated by a double component ( $q s e B C$ ) quorumsensing system (Sperandio et al., 2001). We found that STEC escN (T3SS-ATPase) and qseB mutants were significantly impaired in leaf
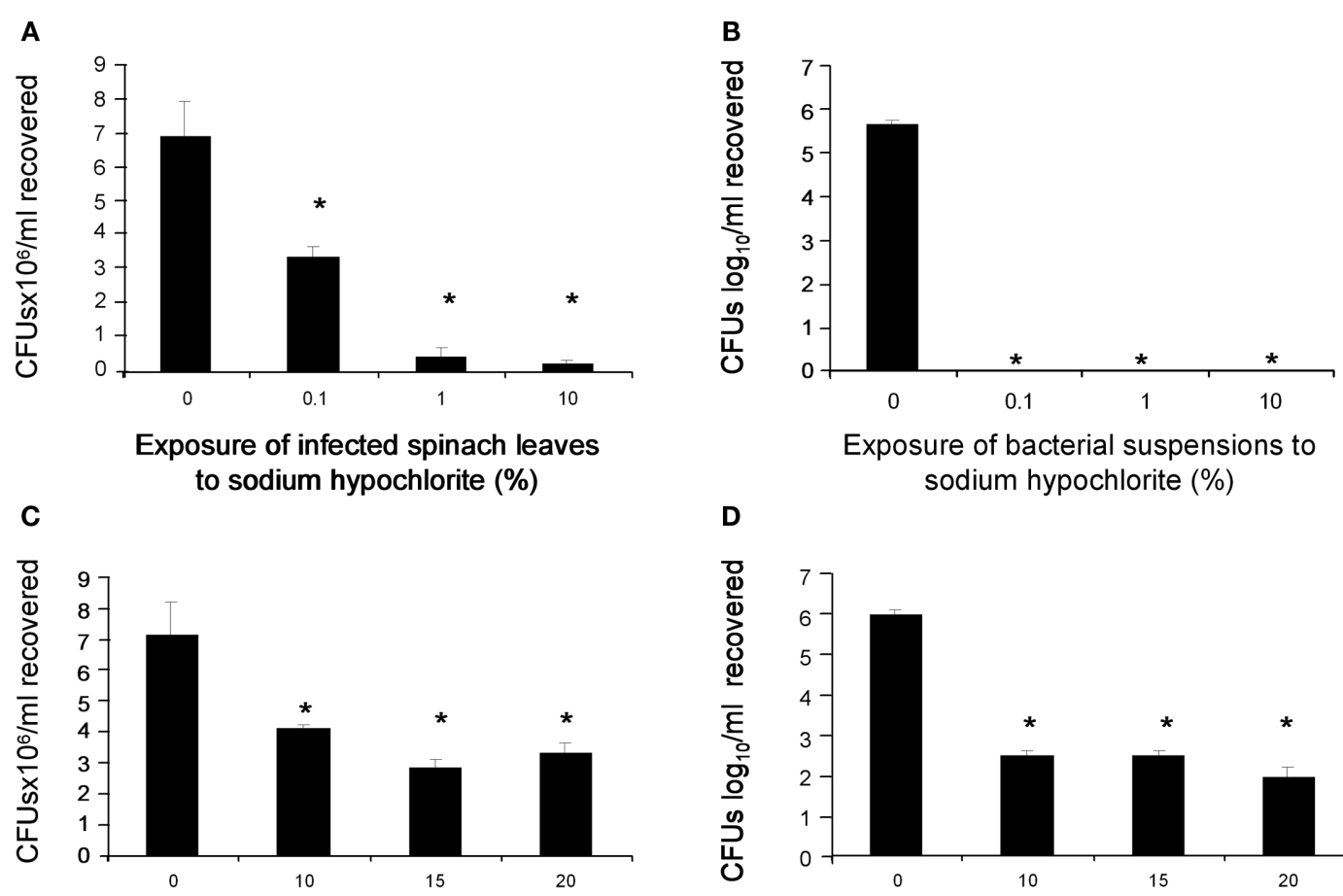

D

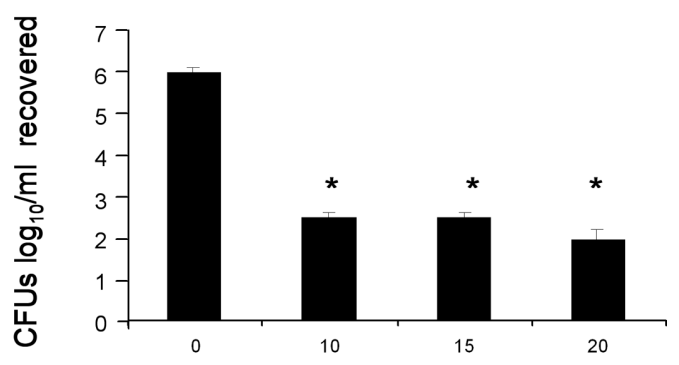

Exposure of infected spinach leaves to ozonated water $(\mathrm{min})$

FIGURE 6 | Survival of STEC within stomata to different decontamination processes. (A) STEC infected-spinach leaves for $9 \mathrm{~h}$ were treated for $10 \mathrm{~min}$ with $0-10 \%$ chlorine solutions and then plated out onto MacConkey-Sorbitol agar. Note that even at $10 \%$ of chlorine wash, the bacteria were able to grow suggesting that they are protected within the stomata. (B) A suspension of $10^{6}$ 
colonization with respect to the parental strain, indicating that the T3SS and cell-to-cell communication are important in the interaction of STEC with plant cells. While the intimin-Tir complex is crucial for attachment and the characteristic development of actinrich processes on host cells, neither intimin nor Tir seemed to be required for leaf adherence. This was somewhat expected given the striking differences in chemical composition between human and plant tissue surfaces.

We sought to investigate if pili and cellulose were required for leaf colonization. Comparative adherence studies employing isogenic pili mutants revealed that curli, ECP, and HCP were required for spinach leaf adherence while ELF and cellulose were apparently not. It is well established that pili, in particular curli, are highly hydrophobic appendages that neutralize negative charges on host cells facilitating adherence (Collinson et al., 1991). Recently, it was shown that the level of adherence of E. coli O157:H7 strains to cabbage and iceberg lettuce surfaces correlated with the amount of curli produced and their hydrophobicity (Patel et al., 2011). The demonstration that several redundant adhesive factors are required for spinach leaf colonization provides an immediate conceptual framework to explain the multiple molecular mechanisms of plant infection by a human pathogen. Future studies will be needed to elucidate the nature of the plant receptors involved in the recognition of STEC fimbrial adhesins.

Plant pathogens are able to breach into internal tissues using wounds and natural openings of the phyllosphere (Hirano and Upper, 2000; Melotto et al., 2006), but the molecular mechanisms employed to penetrate through stomata, as a natural gateway for passage into internal tissues and cause phytopathology are unknown. Compelling data from ultrastructural, genetic, and functional studies described here clearly showed the presence of STEC O157 within stomata and electron microscopy analysis of leaf cross sections revealed the presence of aggregates of bacteria in internal compartments of the leaf such stomata chambers, intercellular spaces, xylem (specifically in vessel elements), and phloem. Experiments designed to evaluate the ability of STEC to survive

\section{REFERENCES}

Berger, C. N., Shaw, R. K., Ruiz-Perez, F., Nataro, J.P., Henderson, I. R., Pallen, M. J., and Frankel, G. (2009). Interaction of enteroaggregative Escherichia coli with salad leaves. Environ. Microbiol. Rep. 1, 234-239.

Berger, C. N., Sodha, S. V., Shaw, R. K., Griffin, P. M., Pink, D., Hand, P., and Frankel, G. (2010). Fresh fruit and vegetables as vehicles for the transmission of human pathogens. Environ. Microbiol. 12, 2385-2397.

Campellone, K. G., Robbins, D., and Leong, J. M. (2004). EspFU is a translocated EHEC effector that interacts with Tir and N-WASP and promotes Nck-independent actin assembly. Dev. Cell 7, 217-228.

Carey, C. M., Kostrzynska, M., and Thompson, S. (2009). Escherichia coli O157:H7 stress and virulence gene expression on Romaine lettuce

within spinach leaves upon treatment with sodium hypochlorite solutions and ozonated water showed that live bacteria could be recovered suggesting that the internal spaces of spinach leaves protect bacteria against these bactericidal agents. We showed that the T3SS is involved in internalization and survival of STEC in spinach leaves. Transformation of a non-pathogenic E. coli with pLEE (T3SS+) rendered the bacteria capable of adhering to the epidermis, internalizing into leaf tissue allowing themselves to survive the bactericidal treatments. It is possible that STEC possess mechanisms that direct them toward stomata (e.g., through chemotaxis, motility, quorum sensing) and induce guard cells to open these gateways. The low-infectious dose of STEC (10-50 organisms) and its ability to colonize the stoma and internal leaf compartments provide logical explanations by which the bacteria survive man-driven decontamination treatments and are able to cause outbreaks of STEC infections associated with consumption of tainted-agricultural products. Thus, infected leafy greens may represent potential vehicles of infection and transmission to humans. In conclusion, our research shows that STEC, a human pathogen, which uses several pili types, flagella and the T3SS to colonize human intestinal tissue, can also employ these mechanisms to gain access to plant leaf surface, internal tissues and intercellular spaces where the bacteria survive in a protected microenvironment before causing disease.

\section{ACKNOWLEDGMENTS}

This work was supported by a grant from Fresh Express Produce and by Grant Number AI66012 from NIAID, NIH to Jorge A. Girón and its contents are solely the responsibility of the authors and do not necessarily represent the official views of the NIH. Jose Luis Puente was supported by CONACyT grant No. 42918Q. We thank Alejandra Vázquez for technical assistance, John M. Leong for kindly providing EDL933 $\Delta$ espFu strain, James B. Kaper for plasmid pLEE, and Karen Kelley and Kim Backer-Kelley at the Interdisciplinary Center for Biotechnology Research, Electron Microscopy and Bio-Imaging, University of Florida for assistance.

Purification and characterization of thin, aggregative fimbriae from Salmonella enteritidis. J. Bacteriol. 173, 4773-4781.

Datsenko, K.A., and Wanner, B. L. (2000). One-step inactivation of chromosomal genes in Escherichia coli K-12 using PCR products. Proc. Natl. Acad. Sci. U.S.A. 97, 6640-6645.

Dziva, F., Mahajan, A., Cameron, P., Currie, C., McKendrick, I. J., Wallis, T. S., Smith, D. G. E., and Stevens, M. P. (2007). EspP, a Type V-secreted serine protease of enterohaemorrhagic Escherichia coli O157:H7, influences intestinal colonization of calves and adherence to bovine primary intestinal epithelial cells. FEMS Microbiol. Lett. 271, 258-264.

Erdem, A. L., Avelino, F., XicohtencatlCortes, J., and Giron, J. A. (2007). Host protein binding and adhesive properties of $\mathrm{H} 6$ and $\mathrm{H} 7$ flagella of attaching and effacing Escherichia coli. J. Bacteriol. 189, 7426-7435.

Franz, E., Visser, A. A., Van Diepeningen, A. D., Klerks, M. M., Termorshuizen, A. J., and van Bruggen, A. H. (2007). Quantification of contamination of lettuce by GFP-expressing Escherichia coli O157:H7 and Salmonella enterica serovar Typhimurium. Food Microbiol. 24, 106-112.

Gorski, L., Palumbo, J. D., and Mandrell, R. E. (2003). Attachment of Listeria monocytogenes to radish tissue is dependent upon temperature and flagellar motility. Appl. Environ. Microbiol. 69, 258-266.

Hirano, S. S., and Upper, C. D. (2000). Bacteria in the leaf ecosystem with emphasis on Pseudomonas syringae-a pathogen, ice nucleus, and epiphyte. Microbiol. Mol. Biol. Rev. 64, 624-653. 803-814.

Collinson, S. K., Emody, L., Muller, K. H., Trust, T. J., and Kay, W. W. (1991).
Islam, M., Doyle, M. P., Phatak, S. C., Millner, P., and Jiang, X. (2004). 
Persistence of enterohemorrhagic Escherichia coli O157:H7 in soil and on leaf lettuce and parsley grown in fields treated with contaminated manure composts or irrigation water. J. Food Prot. 67, 1365-1370.

Itoh, Y., Sugita-Konishi, Y., Kasuga, F., Iwaki, M., Hara-Kudo, Y., Saito, N., Noguchi,Y., Konuma, H., and Kumagai, S. (1998). Enterohemorrhagic Escherichia coli O157:H7 present in radish sprouts. Appl. Environ. Microbiol. 64, 1532-1535.

Jablasone, J., Warriner, K., and Griffiths, M. (2005). Interactions of Escherichia coli O157:H7, Salmonella typhimurium and Listeria monocytogenesplants cultivated in a gnotobiotic system. Int. J. Food Microbiol. 99, 7-18.

Jarvis, K. G., and Kaper, J. B. (1996). Secretion of extracellular proteins by enterohemorrhagic Escherichia colivia a putative type III secretion system. Infect. Immun. 64, 4826-4829.

Jay, M. T., Cooley, M., Carychao, D., Wiscomb, G. W., Sweitzer, R. A., Crawford-Miksza, L., Farrar, J. A., Lau, D. K., O'Connell, J., Millington, A., Asmundson, R.V., Atwill, E. R., and Mandrell, R.E. (2007). Escherichia coli O157:H7 in feral swine near spinach fields and cattle, central California coast. Emerging Infect. Dis. 13, 1908-1911.

Kaper, J. B., Nataro, J. P., and Mobley, H. L. (2004). Pathogenic Escherichia coli. Nat. Rev. Microbiol. 2, 123-140.

Karmali, M. A., Petric, M., Lim, C., Fleming, P. C., and Steele, B. T. (1983). Escherichia colicytotoxin, haemolyticuraemic syndrome, and haemorrhagic colitis. Lancet 2, 1299-1300.

Korhonen, T. K., Haahtela, K., Romantschuk,M., and Bamford, D. H. (1986)."Role of fimbriae and pili in the attachment of Klebsiella, Enterobacter, and Pseudomonas to plant surfaces," in Recognition in Microbe-Plant Symbiotic and Pathogenic Interactions, ed. B. Lugtenberg (Heidelberg: SpringerVerlag), 229-241.

Lindow, S. E., and Brandl, M. T. (2003). Microbiology of the phyllosphere. Appl. Environ. Microbiol. 69, 1875-1883.

Low, A. S., Dziva, F., Torres, A. G., Martinez, J. L., Rosser, T., Naylor, S., Spears, K., Holden, N., Mahajan, A., Findlay, J., Sales, J., Smith, D. G., Low, J. C., Stevens, M. P., and Gally, D. L. (2006). Cloning, expression, and characterization of fimbrial operon $\mathrm{F} 9$ from enterohemorrhagic Escherichia coli O157:H7. Infect. Immun. 74, 2233-2244.

McCullen, C. A., and Binns, A. N. (2006). Agrobacterium tumefaciens and plant cell interactions and activities required for interkingdom macromolecular transfer. Annu. Rev. Cell Dev. Biol. 22, 101-127.

McDaniel, T. K., and Kaper, J. B. (1997). A cloned pathogenicity island from enteropathogenic Escherichia coliconfers the attaching and effacing phenotype on E. coli K-12. Mol. Microbiol. 23, 399-407.

Melotto, M., Underwood, W., Koczan, J., Nomura, K., and He, S.Y. (2006). Plant stomata function in innate immunity against bacterial invasion. Cell 126, 969-980.

Michino, H., Araki, K., Minami, S., Takaya, S., Sakai, N., Miyazaki, M., Ono, A., and Yanagawa, H. (1999). Massive outbreak of Escherichia coli O157:H7 infection in schoolchildren in Sakai City, Japan, associated with consumption of white radish sprouts. Am. J. Epidemiol. 150, 787-796.

Mootian, G., Wu, W. H., and Matthews, K. R. (2009). Transfer of Escherichia coli O157:H7 from soil, water, and manure contaminated with low numbers of the pathogen to lettuce plants. J. Food Prot. 72, 2308-2312.

Patel, J., Sharma, M., and Ravishakar, S. (2011). Effect of curli expression and hydrophobicity of Escherichia coli O157:H7 on attachment to fresh produce surfaces. J. Appl. Microbiol. $110,737-745$.

Rahme, L. G., Stevens, E. J., Wolfort, S. F., Shao, J., Tompkins, R. G., and Ausubel, F. M. (1995). Common virulence factors for bacterial pathogenicity in plants and animals. Science 268, 1899-1902.

Rendon, M. A., Saldana, Z., Erdem, A. L., Monteiro-Neto, V., Vazquez, A., Kaper, J. B., Puente, J. L., and Girón, J. A. (2007). Commensal and pathogenic Escherichia coli use a common pilus adherence factor for epithelial cell colonization. Proc. Natl. Acad. Sci. U.S.A. 104, 10637-10642.

Riley, L. W., Remis, R. S., Helgerson, S. D., McGee, H. B., Wells, J. G., Davis, B. R., Hebert, R. J., Olcott, E. S., Johnson, L. M., Hargrett, N. T., Blake, P. A., and Cohen, M. L. (1983). Hemorrhagic colitis associated with a rare Escherichia coli serotype. N. Engl. J. Med. 308, 681-685.

Saldana, Z., Xicohtencatl-Cortes, J., Avelino, F., Phillips, A. D., Kaper, J. B., Puente, J. L., and Giron, J. A. (2009). Synergistic role of curli and cellulose in cell adherence and biofilm formation of attaching and effacing Escherichia coli and identification of Fis as a negative regulator of curli. Environ. Microbiol. 11, 992-1006.

Samadder, P., Xicohtencatl-Cortes, J., Saldana, Z., Jordan, D., Tarr, P. I.,
Kaper, J. B., and Giron, J. A. (2009). The Escherichia coli ycbQRST operon encodes fimbriae with lamininbinding and epithelial cell adherence properties in Shiga-toxigenic E. coli O157:H7. Environ. Microbiol. 11, 1815-1826.

Sharma, M., Ingram, D. T., Patel, J. R., Millner, P.D., Wang, X., Hull, A. E., and Donnenberg, M. S. (2009). A novel approach to investigate the uptake and internalization of Escherichia col O157:H7 in spinach cultivated in soil and hydroponic medium. J. Food Prot. 72, 1513-1520.

Shaw, R. K., Berger, C.N., Feys, B., Knutton, S., Pallen, M. J., and Frankel, G. (2008). Enterohemorrhagic Escherichia coli exploits EspA filaments for attachment to salad leaves. Appl. Environ. Microbiol. 74, 2908-2914.

Sivapalasingam, S., Friedman, C. R., Cohen, L., and Tauxe, R. V. (2004). Fresh produce: a growing cause of outbreaks of foodborne illness in the United States, 1973 through 1997. J. Food Prot. 67, 2342-2353.

Solomon, E. B., Yaron, S., and Matthews, K. R. (2002). Transmission of Escherichia coli O157:H7 from contaminated manure and irrigation water to lettuce plant tissue and its subsequent internalization. Appl. Environ. Microbiol. $68,397-400$.

Sperandio, V., Torres, A. G., Giron, J. A., and Kaper, J. B. (2001). Quorum sensing is a global regulatory mechanism in enterohemorrhagic Escherichia coli O157:H7. J. Bacteriol. 183, 5187-5197.

Talley, J. L., Wayadande, A. C., Wasala, L. P., Gerry, A. C., Fletcher, J., DeSilva, U., and Gilliland, S. E. (2009). Association of Escherichia coli O157:H7 with filth flies (Muscidae and Calliphoridae) captured in leafy greens fields and experimental transmission of E. coli O157:H7 to spinach leaves by house flies (Diptera: Muscidae). J. Food Prot. 72, 1547-1552.

Torres, A. G., Giron, J. A., Perna, N. T., Burland, V., Blattner, F. R., AvelinoFlores, F., and Kaper, J. B. (2002). Identification and characterization of lpfABCC'DE, a fimbrial operon of enterohemorrhagic Escherichia coli O157:H7. Infect. Immun. 70, 5416-5427.

Vesper, S. J. (1987). Production of Pili (Fimbriae) by Pseudomonas fluorescens and correlation with attachment to corn roots. Appl. Environ. Microbiol. 53, 1397-1405.

Wachtel, M. R., Whitehand, L. C., and Mandrell, R. E. (2002). Association of Escherichia coli O157:H7 with preharvest leaf lettuce upon exposure to contaminated irrigation water. J. Food Prot. 65, 18-25.

Warriner, K., Ibrahim, F., Dickinson, M., Wright, C., and Waites, W. M. (2003). Interaction of Escherichia coli with growing salad spinach plants. J. Food Prot. 66, 1790-1797.

Wendel, A. M., Johnson, D. H., Sharapov, U., Grant, J., Archer, J. R., Monson, T., Koschmann, C., and Davis, J.P. (2009). Multistate outbreak of Escherichia coli O157:H7 infection associated with consumption of packaged spinach, August-September 2006: the Wisconsin investigation. Clin. Infect. Dis. 48, 1079-1086.

Xicohtencatl-Cortes, J., Chacón, E. S. Saldaña, Z., Freer, E., and Girón, J. A. (2009). Interaction of Escherichia coli O157:H7 with Leafy Green Produce J. Food Prot. 72, 1531-1537.

Xicohtencatl-Cortes, J., Monteiro-Neto, V., Ledesma, M. A., Jordan, D. M., Francetic, O., Kaper, J. B., Puente, J. L., and Girón, J. A. (2007). Intestinal adherence associated with type IV pili of enterohemorrhagic Escherichia coli O157:H7. J. Clin. Invest. 117, 3519-3529.

Xicohtencatl-Cortes, J., Saldana, Z., Deng, W., Castaneda, E., Freer, E., Tarr, P. I., Finlay, B. B., Puente, J. L., and Girón, J. A. (2010). Bacterial macroscopic rope-like fibers with cytopathic and adhesive properties. J. Biol. Chem.285, 32336-32342.

Conflict of Interest Statement: The authors declare that the research was conducted in the absence of any commercial or financial relationships that could be construed as a potential conflict of interest.

Received: 01 September 2010; accepted: 12 May 2011; published online: 27 May 2011.

Citation: Saldaña Z, Sánchez E, Xicohtencatl-Cortes J, Puente JL and Girón JA (2011) Surface structures involved in plant stomata and leaf colonization by Shiga-toxigenic Escherichia coli O157:H7. Front. Microbio. 2:119. doi: 10.3389/ fmicb.2011.00119

This article was submitted to Frontiers in Cellular and Infection Microbiology, a specialty of Frontiers in Microbiology. Copyright (c) 2011 Saldaña, Sánchez, Xicohtencatl-Cortes, Puente and Girón. This is an open-access article subject to a non-exclusive license between the authors and Frontiers Media SA, which permits use, distribution and reproduction in other forums, provided the original authors and source are credited and other Frontiers conditions are complied with. 